\title{
Estimation of Energy Requirement of Jatropha Curcas L. Seedcake Briquettes under Compression Loading
}

\author{
Tatiana Ivanova $^{1, *(1)}$, Abraham Kabutey ${ }^{2}$ (i) ${ }^{\text {David Herák }}{ }^{2}$ and Cimen Demirel ${ }^{3}$ \\ 1 Department of Sustainable Technologies, Faculty of Tropical AgriSciences, Czech University of Life \\ Sciences Prague, Prague 16521, Czech Republic \\ 2 Department of Mechanical Engineering, Faculty of Engineering, Czech University of Life Sciences Prague, \\ Prague 16521, Czech Republic; kabutey@tf.czu.cz (A.K.); herak@tf.czu.cz (D.H.) \\ 3 Department of Agricultural Machinery, Faculty of Agriculture, Ondokuz Mayis University, Samsun 55139, \\ Turkey; cimen.demirel@omu.edu.tr \\ * Correspondence: ivanova@ftz.czu.cz; Tel.: +420-224382603
}

Received: 26 June 2018; Accepted: 28 July 2018; Published: 30 July 2018

\begin{abstract}
The energy requirement of Jatropha curcas L. seedcake of different dimensions (4.5, 5.6, 6.7, 8 and $10 \mathrm{~mm}$ ) for briquette compaction was investigated under compression loading $(100,200,300$ and $400 \mathrm{kN}$ ) using the universal compression-testing machine. The parameters measured and/or calculated were the deformation, thickness, numerical energy and theoretical energy. The statistical analysis results show that compression forces had a significant effect $(p$-value $<0.05)$ on the amounts of deformation and thickness, while that of the dimensions of the sample did not. The increase in compression forces increased the numerical energy while that of samples dimensions caused a decrease. Using the tangent curve mathematical model; the force coefficient of mechanical behaviour $(\mathrm{kN})$, the deformation coefficient of mechanical behaviour and the fitting curve function exponent were determined for describing the experimental dependency between the force and deformation curves as well as the numerical energies of densified jatropha seedcake briquettes.
\end{abstract}

Keywords: jatropha seedcake; briquettes compaction; energy consumption; force-deformation curve; economic value

\section{Introduction}

Jatropha curcas L. is a multipurpose perennial oil-bearing plant that belongs to the family Euphorbiaceae with a life expectancy of 50 years [1-3]. The production of oil requires de-husking and oil extraction processes [2]. About 50 to $70 \%$ of the original seed weight remains as de-oiled seedcake, a by-product after oil extraction. Fruit husk and seedcake have wide-ranging applications as fuel and organic fertilizers or soil conditioners. The seedcake containing high protein can be used as animal feed after further processing and detoxification $[2,4]$. With the rapid population and economic growth, the energy utilization has been increasing greatly [5]. In the global energy mix, fossil fuels remain the primary energy source that has been associated with the increase of carbon dioxide emissions. The use of renewable energy sources such as biomass is essential in reducing greenhouse emissions and fossil fuel dependency [6-8]. Worldwide, biomass is the third-largest primary energy after coal and oil being the main source of energy for half the world's population [5,9].

Agricultural and industrial residues such as husk, rice bran, rice straw, corn straw, corn cob, bagasse and de-oiled seedcakes can be utilized by the biomass-to-energy conversion processes including but not limited to direct combustion, gasification, pyrolysis, anaerobic digestion, hydrolysis, hydrogenation or fermentation [5,10-12]. These processes, however, are energy and equipment intensive $[9,13]$. Following the literature, biomass briquetting technologies available include mechanical 
piston press, screw press, hydraulic press and roller press [9]. Other technologies reported include high-pressure compaction, medium-pressure compaction aided by the heating device and low compaction pressure [14]. Compaction pressure, material moisture content, fraction particle of the initial material, pressing temperature, durability, material or particle density, etc. are important parameters for assessing the quality of densified biomass [15-20]. In the densification process, the mechanical pressure creates bonds between the particulate matter. Natural binders such as lignin, proteins, fats, starch and water-soluble carbohydrates also produce solid bridges between the particles [15]. In order to improve compaction equipment design, reduce energy consumption and improve the quality of products, it is important to understand the mechanical and/or rheological behaviour of biomass materials. The present study aimed at estimating the energy demand and describing the mechanical properties of Jatropha curcas L. seedcake of different size distributions under compression loading using a universal compression-testing machine and a pressing chamber with a piston.

\section{Materials and Methods}

Samples of bulk Jatropha curcas L. seedcake of 7.5\% moisture content on wet basis were used for the briquette densification. Sample size distributions of 4.5, 5.6, 6.7, 8 and $10 \mathrm{~mm}$ were determined using a horizontal sieve shaker (Retsch AS 200, Germany) for 30 minutes at an amplitude of $3.0 \mathrm{~mm} /$ "g", according to the standard [21,22]. The moisture content was determined using the standard oven-drying method [23-25]. The universal compression-testing machine (ZDM 50, Czech Republic) was used for the densification process by applying the compression forces $F_{C}$ from 100, 200, 300 to $400 \mathrm{kN}$ of equivalent pressures $P_{R}$ from $35.37,70.74,106.10$ to $141.47 \mathrm{MPa}$ at a constant speed of $5 \mathrm{~mm} \mathrm{~min}{ }^{-1}$. The initial height of the samples $H_{i}$ was measured at $60 \mathrm{~mm}$ using the pressing vessel of diameter $60 \mathrm{~mm}$ (Figure 1). Each sample was replicated twice, making 40 experiments in total.

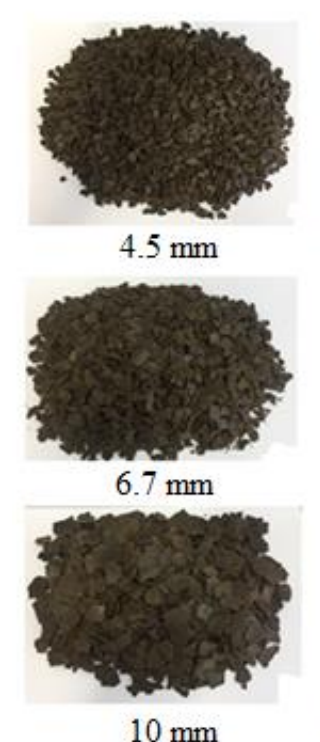

$10 \mathrm{~mm}$

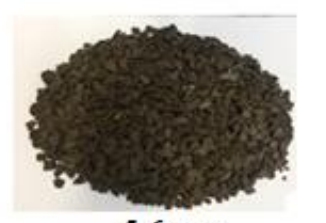

$5.6 \mathrm{~mm}$

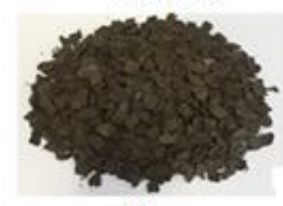

$8 \mathrm{~mm}$

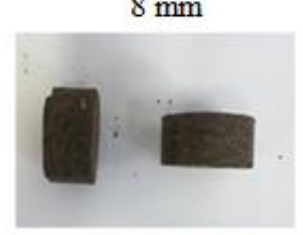

Jatropha seedcake briquettes

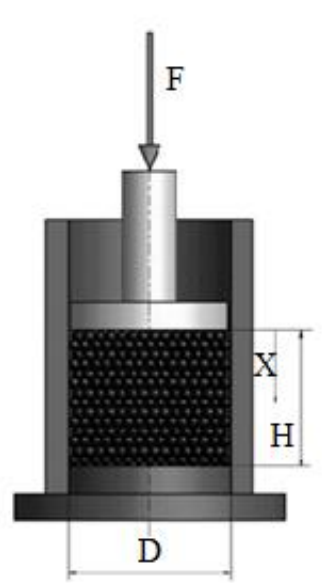

(B)

(A)

Figure 1. (A) Jatropha seedcake of varying size distributions, (B) schematic of the pressing vessel with diameter $\mathrm{D}=60 \mathrm{~mm}$ and a plunger (F-Force, $\mathrm{H}$-Initial height of sample, $\mathrm{X}$-Deformation of samples), reprinted from publication [26].

The following parameters were calculated respectively. The volume of samples was calculated using Equation (1) as follows:

$$
V_{L}=\frac{\pi \cdot D^{2}}{4} \cdot H_{i}
$$


where $V_{L}$ is the volume of samples $\left(\mathrm{m}^{3}\right), D$ is the diameter of pressing vessel (mm) and $H_{i}$ is the initial height of samples ( $\mathrm{mm}$ ). The volume of densified briquettes was calculated using Equation (2) as follows:

$$
V_{B}=\frac{\pi \cdot D^{2}}{4} \cdot T_{X}
$$

where $V_{B}$ is the volume of densified briquettes $\left(\mathrm{m}^{3}\right)$ and $T_{X}$ is the thickness of densified briquettes $(\mathrm{mm})$. The density of samples was calculated using Equation (3) as follows:

$$
D_{S}=\frac{M_{S}}{V_{L}}
$$

where $D_{S}$ is the density of samples $\left(\mathrm{kg} \mathrm{m}^{-3}\right), M_{S}$ is the initial mass of samples $(0.103 \mathrm{~kg})$. The density of densified briquettes was calculated using Equation (4) as follows:

$$
D_{B}=\frac{M_{S}}{V_{B}}
$$

where $D_{B}$ is the density of the densified briquettes $\left(\mathrm{m}^{3}\right)$. The hardness of the densified briquettes was calculated using Equation (5) as follows:

$$
H_{D}=\frac{F_{C}}{\delta_{X}}
$$

where $H_{D}$ is the hardness of densified briquettes $\left(\mathrm{kN} \mathrm{mm}^{-1}\right), F_{C}$ is the compression force $(\mathrm{N})$ and $\delta_{X}$ is the deformation of densified briquettes ( $\mathrm{mm}$ ). The pressure was calculated based on Equation (6) as follows:

$$
P_{R}=\frac{F_{C}}{A_{X}}
$$

where $P_{R}$ is the pressure (MPa) and $A_{X}$ is the area of pressing vessel $\left(\mathrm{mm}^{2}\right)$ defined in Equation (7) as follows:

$$
A_{X}=\frac{\pi \cdot D^{2}}{4}
$$

The numerical energy of the densified briquettes [27-29] was calculated using Equation (8) as follows:

$$
E_{N}=\sum_{n=0}^{n=i-1}\left[\left(\frac{F_{n+1}+F_{n}}{2}\right) \cdot\left(x_{n+1}-x_{n}\right)\right]
$$

where $E_{N}$ is the numerical energy of the densified briquettes (J), $F_{n+1}+F_{n}$ and $x_{n+1}-x_{n}$ are the values of the compression force $(\mathrm{N})$ and deformation $(\mathrm{mm}), n$ is the number of data points and $i$ is the number of subsections of the deformation axis (-). The energy per unit volume of the densified briquettes was calculated using Equation (9) $[30,31]$ as follows:

$$
V_{E}=\frac{E_{N}}{V_{B}}
$$

where $V_{E}$ is the volume energy of the densified briquettes $\left(\mathrm{m}^{3}\right)$. The tangent curve model [26,32-34] was used to describe the theoretical dependency between the force and deformation curves of the densified briquettes, where the theoretical energy was determined. The tangent curve mathematical model is given in Equation (10) as follows:

$$
F(X)=A \cdot(\tan (B \cdot X))^{n}
$$

where $F$ is the compression force $(\mathrm{kN})$ and $X$ is the deformation of the densified briquettes $(\mathrm{mm})$, $A$ is the force coefficient of mechanical behaviour $(\mathrm{kN}), B$ is the deformation coefficient of mechanical 
behaviour $\left(\mathrm{mm}^{-1}\right)$ and $n$ is the value of the fitting function (-). The deformation $X$ of each densified briquette was obtained from the plot of the force-deformation curve after the densification process. The coefficients $A, B$ and $n$ were determined using Mathcad 14 software based on the experimental relationship between the force and deformation curve. The use of the tangent curve model satisfies the boundary conditions of the densification test: zero compression force relates to zero deformation, compression force approaching infinity relates to limit deformation and integral of the tangent curve model relates to energy [26,32-34]. The data were analysed using the Mathcad software, version 14 and STATISTICA, version 13 [35,36].

\section{Results}

The amounts of deformation $\delta_{X}$, thickness $T_{X}$, numerical energy $E_{N}$ and theoretical energy $E_{T}$ of densified briquettes of jatropha seedcake grouped by compression forces and samples dimensions are presented in Table 1, and graphically displayed in Figures 2-5, respectively.

The volume, density, hardness and volume energy of densified briquettes of jatropha seedcake at varying forces and dimensions are also given in Table 2.

Table 1. Dependent variables of the jatropha seedcake briquettes compaction at varying forces and dimensions (Mean \pm Standard Deviation).

\begin{tabular}{|c|c|c|c|c|c|}
\hline $\begin{array}{l}\text { Force } F_{C} \\
\quad(\mathbf{k N})\end{array}$ & $\begin{array}{c}\underset{(\mathrm{mm})}{\operatorname{Dimensions}} D_{m} \\
\end{array}$ & $\begin{array}{c}\text { Deformation } \delta_{X} \\
(\mathrm{~mm})\end{array}$ & $\begin{array}{l}\text { Thickness } T_{X} \\
\text { (mm) }\end{array}$ & $\begin{array}{c}* \text { Numerical Energy } \\
E_{N}(\mathrm{~J})\end{array}$ & $\begin{array}{c}* * \text { Theoretical Energy } \\
E_{T}(\mathrm{~J})\end{array}$ \\
\hline \multirow{5}{*}{100} & 4.5 & $29.79 \pm 0.24$ & $35.44 \pm 0.34$ & $455.28 \pm 2.55$ & $464.50 \pm 24.76$ \\
\hline & 5.6 & $35.39 \pm 2.50$ & $35.35 \pm 0.21$ & $445.76 \pm 12.45$ & $485.1 \pm 17.77$ \\
\hline & 6.7 & $33.24 \pm 5.55$ & $35.66 \pm 1.19$ & $433.46 \pm 2.46$ & $451.72 \pm 22.76$ \\
\hline & 8 & $39.39 \pm 3.35$ & $35.75 \pm 0.36$ & $429.41 \pm 5.81$ & $471.87 \pm 32.54$ \\
\hline & 10 & $29.08 \pm 1.83$ & $34.89 \pm 0.16$ & $398.8 \pm 8.40$ & $420.74 \pm 0.45$ \\
\hline \multirow{5}{*}{200} & 4.5 & $39.45 \pm 0.94$ & $33.12 \pm 0.54$ & $897.70 \pm 12.64$ & $1074.67 \pm 15.15$ \\
\hline & 5.6 & $39.18 \pm 2.85$ & $33.11 \pm 0.56$ & $886.53 \pm 4.52$ & $943.31 \pm 92.11$ \\
\hline & 6.7 & $39.28 \pm 2.98$ & $33.22 \pm 0.41$ & $871.47 \pm 5.54$ & $1037.97 \pm 43.12$ \\
\hline & 8 & $43.12 \pm 1.91$ & $33.12 \pm 0.17$ & $865.59 \pm 19.25$ & $975.69 \pm 32.17$ \\
\hline & 10 & $34.38 \pm 9.33$ & $33.34 \pm 1.64$ & $851.28 \pm 45.09$ & $926.59 \pm 101.63$ \\
\hline \multirow{5}{*}{300} & 4.5 & $41.09 \pm 1.63$ & $31,42 \pm 0.11$ & $1345.41 \pm 9.25$ & $1508.88 \pm 20.66$ \\
\hline & 5.6 & $40.69 \pm 4.86$ & $30.99 \pm 0.02$ & $1315.45 \pm 7.55$ & $1456.07 \pm 49.21$ \\
\hline & 6.7 & $40.71 \pm 3.44$ & $31.61 \pm 0.66$ & $1321.35 \pm 15.87$ & $1350.16 \pm 21.43$ \\
\hline & 8 & $38.12 \pm 4.56$ & $31.31 \pm 0.43$ & $1297.63 \pm 6.01$ & $1477.62 \pm 83.26$ \\
\hline & 10 & $37.23 \pm 2.12$ & $32.07 \pm 2.03$ & $1253.27 \pm 75.74$ & $1459.10 \pm 40.56$ \\
\hline \multirow{5}{*}{400} & 4.5 & $43.33 \pm 1.16$ & $30.54 \pm 0.06$ & $1683.42 \pm 4.47$ & $1751.20 \pm 44.29$ \\
\hline & 5.6 & $40.59 \pm 5.58$ & $30.70 \pm 0.42$ & $1657.82 \pm 8.49$ & $1894.03 \pm 68.11$ \\
\hline & 6.7 & $39.17 \pm 7.01$ & $30.49 \pm 0.01$ & $1536.92 \pm 73.51$ & $1781.31 \pm 38.34$ \\
\hline & 8 & $43.21 \pm 8.14$ & $30.64 \pm 0.51$ & $1640.81 \pm 40.70$ & $1738.05 \pm 131.15$ \\
\hline & 10 & $44.64 \pm 0.42$ & $31.04 \pm 0.65$ & $1509.59 \pm 79.26$ & $1512.78 \pm 68.39$ \\
\hline
\end{tabular}

${ }^{*}$ Equation (8), ${ }^{* *}$ Equation (17).

Table 2. Volume, density and hardness of jatropha seedcake briquettes compaction at varying forces and dimensions (Mean \pm Standard Deviation).

\begin{tabular}{|c|c|c|c|c|c|}
\hline $\begin{array}{l}\text { Force } F_{C} \\
(\mathbf{k N})\end{array}$ & $\begin{array}{c}\text { Dimensions } D_{m} \\
(\mathrm{~mm})\end{array}$ & $\begin{array}{c}* * * \text { Volume } V_{B} \\
\left(10^{-5} \mathrm{~m}^{3}\right)\end{array}$ & $\begin{array}{c}* * \text { Density } D_{B} \\
\left(\mathrm{~kg} \mathrm{~m}^{-3}\right)\end{array}$ & $\begin{array}{c}* * * \text { Hardness } H_{D} \\
\left(\mathrm{kN} \mathrm{mm}^{-1}\right)\end{array}$ & $\begin{array}{l}\text { *** Volume Energy } V_{E} \\
\left(10^{6} \mathrm{~J} \mathrm{~m}^{-3}\right)\end{array}$ \\
\hline \multirow{5}{*}{100} & 4.5 & $10 \pm 0.10$ & $1223 \pm 10$ & $3.36 \pm 0.03$ & $4.56 \pm 0.05$ \\
\hline & 5.6 & $10 \pm 0.10$ & $1032 \pm 73$ & $2.83 \pm 0.20$ & $4.24 \pm 0.03$ \\
\hline & 6.7 & $9.7 \pm 0.30$ & $1111 \pm 19$ & $3.05 \pm 0.51$ & $6.83 \pm 3.87$ \\
\hline & 8 & $9.5 \pm 0.00$ & $928 \pm 79$ & $2.55 \pm 0.22$ & $9.28 \pm 0.06$ \\
\hline & 10 & $9.5 \pm 0.30$ & $1255 \pm 79$ & $3.45 \pm 0.22$ & $9.24 \pm 0.26$ \\
\hline \multirow{5}{*}{200} & 4.5 & $8.8 \pm 0.10$ & $924 \pm 22$ & $5.07 \pm 0.12$ & $14.99 \pm 0.06$ \\
\hline & 5.6 & $8.9 \pm 0.20$ & $932 \pm 68$ & $5.12 \pm 0.37$ & $14.62 \pm 0.12$ \\
\hline & 6.7 & $9.0 \pm 0.60$ & $930 \pm 71$ & $5.11 \pm 0.39$ & $16.68 \pm 4.07$ \\
\hline & 8 & $8.7 \pm 0.10$ & $846 \pm 37$ & $4.64 \pm 0.21$ & $18.70 \pm 0.39$ \\
\hline & 10 & $8.8 \pm 0.10$ & $1100 \pm 31$ & $6.04 \pm 1.64$ & $17.99 \pm 0.57$ \\
\hline
\end{tabular}


Table 2. Cont.

\begin{tabular}{|c|c|c|c|c|c|}
\hline $\begin{array}{l}\text { Force } F_{C} \\
(\mathbf{k N})\end{array}$ & $\begin{array}{c}\text { Dimensions } D_{m} \\
(\mathrm{~mm})\end{array}$ & $\begin{array}{c}* * * \text { Volume } V_{B} \\
\left(10^{-5} \mathrm{~m}^{3}\right)\end{array}$ & $\begin{array}{c}* * * \text { Density } D_{B} \\
\left(\mathrm{~kg} \mathrm{~m}^{-3}\right)\end{array}$ & $\begin{array}{c}* * * \text { Hardness } H_{D} \\
\left(\mathrm{kN} \mathrm{mm}^{-1}\right)\end{array}$ & $\begin{array}{c}* * * \text { Volume Energy } V_{E} \\
\left(10^{6} \mathrm{~J} \mathrm{~m}^{-3}\right)\end{array}$ \\
\hline \multirow{5}{*}{300} & 4.5 & $10 \pm 0.10$ & $887 \pm 35$ & $7.31 \pm 0.29$ & $4.44 \pm 0.07$ \\
\hline & 5.6 & $9.9 \pm 0.10$ & $902 \pm 11$ & $7.43 \pm 0.89$ & $4.31 \pm 0.10$ \\
\hline & 6.7 & $9.5 \pm 0.40$ & $898 \pm 76$ & $7.40 \pm 0.62$ & $6.79 \pm 3.96$ \\
\hline & 8 & $9.3 \pm 0.00$ & $963 \pm 12$ & $7.93 \pm 0.95$ & $9.47 \pm 0.22$ \\
\hline & 10 & $9.2 \pm 0.20$ & $980 \pm 56$ & $8.07 \pm 0.46$ & $9.04 \pm 0.04$ \\
\hline \multirow{5}{*}{400} & 4.5 & $8.8 \pm 0.10$ & $841 \pm 23$ & $9.24 \pm 0.25$ & $15.17 \pm 0.12$ \\
\hline & 5.6 & $8.9 \pm 0.10$ & $906 \pm 13$ & $9.95 \pm 1.37$ & $14.83 \pm 0.38$ \\
\hline & 6.7 & $8.7 \pm 0.00$ & $945 \pm 17$ & $10.38 \pm 1.86$ & $16.64 \pm 3.95$ \\
\hline & 8 & $8.6 \pm 0.00$ & $858 \pm 16$ & $9.42 \pm 1.78$ & $18.22 \pm 1.40$ \\
\hline & 10 & $8.6 \pm 0.10$ & $816 \pm 80$ & $8.96 \pm 0.09$ & $18.16 \pm 1.90$ \\
\hline
\end{tabular}

*** Jatropha seedcake briquettes based on Equations (1), (4), (5) and (9).

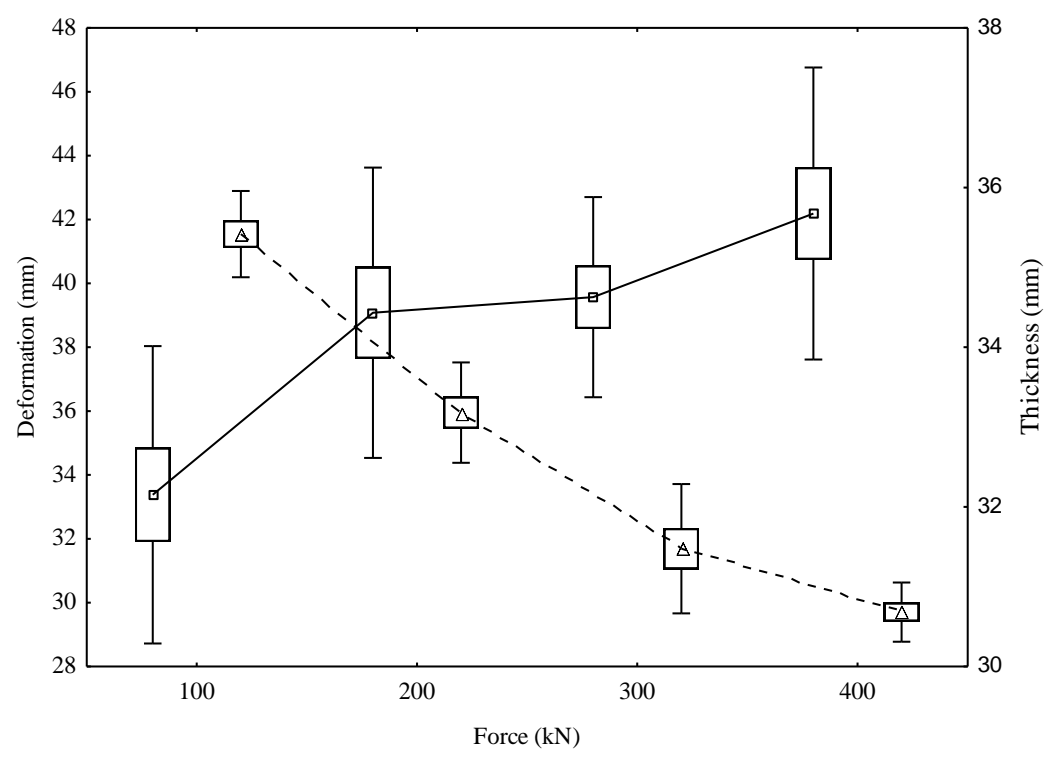

回 Deformation (mm) $\otimes$ Thickness (mm)

Figure 2. Box plot of deformation and thickness of samples grouped by force.

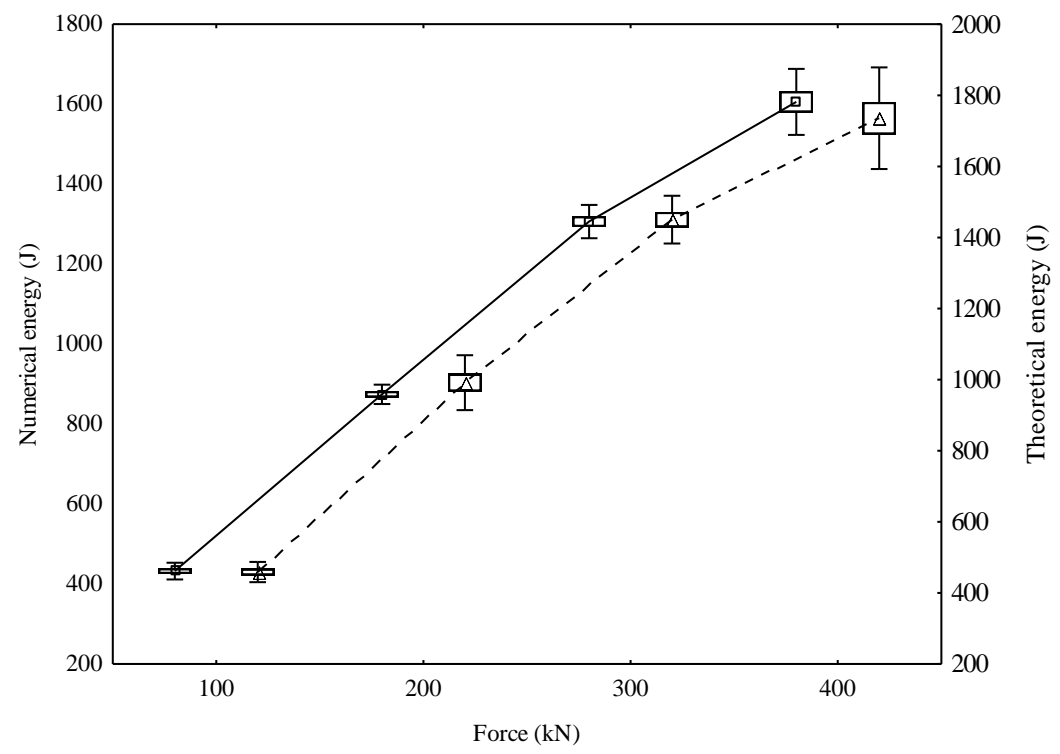

回 Numerical energy (J) 国 Theoretical energy (J)

Figure 3. Box plot of numerical and theoretical deformation energy of samples grouped by force. 


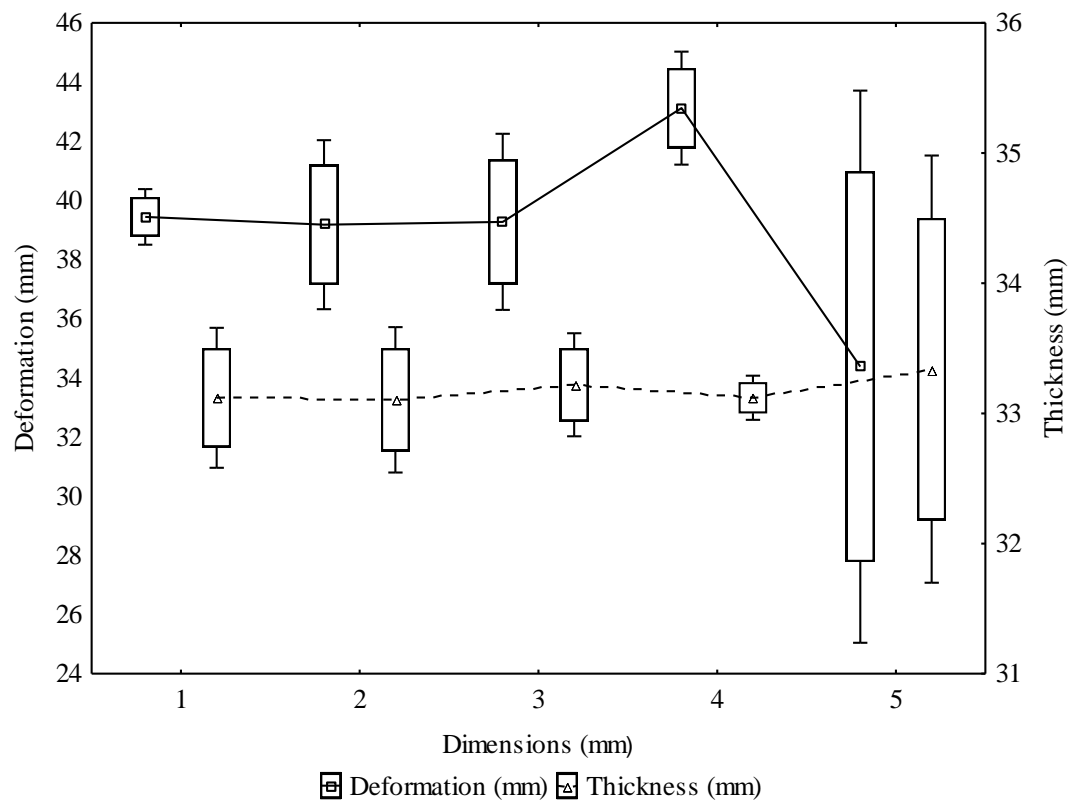

Figure 4. Box plot of deformation and thickness grouped by sample dimensions $(1=4.5 \mathrm{~mm}$; $2=5.6 \mathrm{~mm} ; 3=6.7 \mathrm{~mm} ; 4=8 \mathrm{~mm}$ and $5=10 \mathrm{~mm}$ ) at force $200 \mathrm{kN}$, similar to forces 100,300 and $400 \mathrm{kN}$.

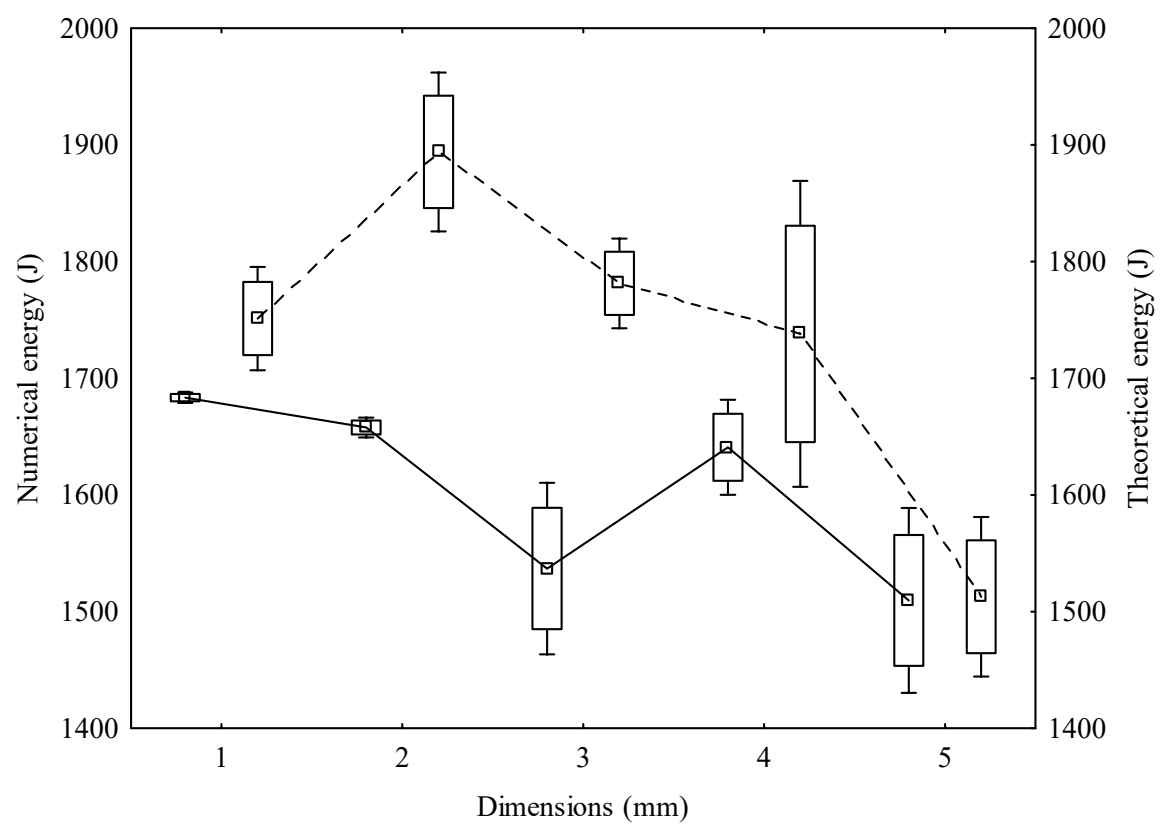

回 Numerical energy (J) 回 Theoretical energy (J)

Figure 5. Box plot of numerical and theoretical energy grouped by sample dimensions $(1=4.5 \mathrm{~mm}$; $2=5.6 \mathrm{~mm} ; 3=6.7 \mathrm{~mm} ; 4=8 \mathrm{~mm}$ and $5=10 \mathrm{~mm}$ ) at force $400 \mathrm{kN}$, similar to forces 100,200 and $300 \mathrm{kN}$.

The multiple regression statistical results of the dependent variables of jatropha seedcake briquette compaction (deformation, thickness, numerical energy and theoretical energy) in relation to the effects of compression forces and samples dimensions are given in Tables 3 and 4. 
Table 3. Multiple regression analysis of dependent variables in relation to the effect of compression forces and samples dimensions.

\begin{tabular}{ccccc}
\hline Dependent Variables & $\mathbf{R}^{\mathbf{2}}(-)$ & F-Ratio (-) & F-Critical (-) & $p$-Value (-) \\
\hline Deformation $\delta_{X}(\mathrm{~mm})$ & 0.34 & 9.61 & 1.42 & $<0.05$ \\
Thickness $T_{X}(\mathrm{~mm})$ & 0.87 & 127.99 & 1.42 & $<0.05$ \\
Numerical energy $E_{N}(\mathrm{~J})$ & 0.99 & 1295.19 & 1.42 & $<0.05$ \\
Theoretical energy $E_{T}(\mathrm{~J})$ & 0.96 & 443.35 & 1.42 & $<0.05$ \\
\hline
\end{tabular}

$p$-value $<0.05$ or F-ratio $>$ F-critical means statistically significant [36].

Table 4. Simple regression analysis of dependent variables in relation to the effect of compression forces.

\begin{tabular}{ccccc}
\hline Dependent Variables & $\mathbf{R}^{\mathbf{2}}(-)$ & F-Ratio (-) & F-Critical (-) & $p$-Value (-) \\
\hline Deformation $\delta_{X}(\mathrm{~mm})$ & 0.34 & 19.43 & 1.60 & $<0.05$ \\
Thickness $T_{X}(\mathrm{~mm})$ & 0.87 & 258.61 & 1.60 & $<0.05$ \\
\hline
\end{tabular}

$p$-value $<0.05$ or F-ratio $>$ F-critical means statistically significant [36].

The Analysis of variance (ANOVA) statistical results of the determined coefficients of the tangent curve model (Equation (10)) using Mathcad 14 software for a level of significance of $5 \%$ are given in Tables 5 and 6 respectively.

Table 5. Determined coefficients $(A, B, n)$ and their statistical analysis for the calculation of the theoretical energy of jatropha seedcake briquettes at a forces 100 and $200 \mathrm{kN}$.

\begin{tabular}{ccccccccc}
\hline $\begin{array}{c}\text { Force } \boldsymbol{F}_{\boldsymbol{C}} \\
\mathbf{( k N )}\end{array}$ & $\begin{array}{c}\text { Dimensions } \\
\boldsymbol{D}_{\boldsymbol{m}} \mathbf{( \mathbf { m m } )}\end{array}$ & $\boldsymbol{A} \mathbf{( k N )}$ & $\boldsymbol{B}\left(\mathbf{m m}^{-\mathbf{1}}\right)$ & $\boldsymbol{n} \mathbf{( - )}$ & F-Ratio (-) & F-Critical (-) & $\boldsymbol{P - V a l u e ~ ( - )}$ & $\mathbf{R}^{\mathbf{2}} \mathbf{( - )}$ \\
\hline & 4.5 & $1.01 \pm 0.01$ & $0.042 \pm 0.001$ & & $0.008 \pm 0.001$ & $3.863 \pm 0.007$ & $0.927 \pm 0.006$ & $0.999 \pm 0.001$ \\
& 5.6 & $6.91 \pm 1.41$ & $0.038 \pm 0.002$ & & $0.029 \pm 0.009$ & $3.866 \pm 0.011$ & $0.866 \pm 0.023$ & $0.998 \pm 0.001$ \\
100 & 6.7 & $7.96 \pm 3.01$ & $0.039 \pm 0.004$ & 2 & $0.024 \pm 0.002$ & $3.868 \pm 0.004$ & $0.878 \pm 0.004$ & $0.998 \pm 0.001$ \\
& 8 & $5.07 \pm 1.03$ & $0.035 \pm 0.002$ & & $0.062 \pm 0.027$ & $3.867 \pm 0.008$ & $0.806 \pm 0.041$ & $0.996 \pm 0.001$ \\
& 10 & $8.54 \pm 1.34$ & $0.045 \pm 0.002$ & & $0.033 \pm 0.013$ & $3.871 \pm 0.011$ & $0.859 \pm 0.029$ & $0.997 \pm 0.001$ \\
\hline & 4.5 & $11.16 \pm 0.72$ & $0.035 \pm 0.001$ & & $0.072 \pm 0.016$ & $3.862 \pm 0.007$ & $0.789 \pm 0.023$ & $0.996 \pm 0.001$ \\
& 5.6 & $13.76 \pm 5.22$ & $0.037 \pm 0.004$ & & $0.045 \pm 0.009$ & $3.868 \pm 0.009$ & $0.832 \pm 0.018$ & $0.997 \pm 0.001$ \\
& 6.7 & $9.72 \pm 0.07$ & $0.034 \pm 0.001$ & 2 & $0.093 \pm 0.081$ & $3.867 \pm 0.012$ & $0.775 \pm 0.107$ & $0.996 \pm 0.001$ \\
& 8 & $10.79 \pm 4.16$ & $0.034 \pm 0.005$ & & $0.062 \pm 0.008$ & $3.865 \pm 0.008$ & $0.803 \pm 0.013$ & $0.995 \pm 0.002$ \\
& 10 & $11.84 \pm 4.10$ & $0.036 \pm 0.004$ & & $0.064 \pm 0.021$ & $3.867 \pm 0.007$ & $0.801 \pm 0.032$ & $0.995 \pm 0.001$ \\
\hline
\end{tabular}

$A$ is the force coefficient of mechanical behaviour $(\mathrm{kN}), B$ is the deformation coefficient of mechanical behaviour $\left(\mathrm{mm}^{-1}\right), n$ is the fitting curve function exponent $(-)$, F-ratio is the value of the F test $(-)$, F-critical is the critical value that compares a pair of models $(-), p$ value is the significance level used for testing a statistical hypothesis $(-), \mathrm{R}^{2}$ is the coefficient of determination (-). $p$-value $>0.05$ or F-critical $>$ F-ratio means statistically significant [35].

Table 6. Determined coefficients $(A, B, n)$ and their statistical analysis for the calculation of the theoretical energy of jatropha seedcake briquettes at a forces 300 and $400 \mathrm{kN}$.

\begin{tabular}{ccccccccc}
\hline $\begin{array}{c}\text { Force } \boldsymbol{F}_{\boldsymbol{C}} \\
(\mathbf{k N})\end{array}$ & $\begin{array}{c}\text { Dimensions } \\
\boldsymbol{D}_{\boldsymbol{m}} \mathbf{( \mathbf { m m } )}\end{array}$ & $\boldsymbol{A} \mathbf{( k N )}$ & $\boldsymbol{B}\left(\mathbf{m m}^{-\mathbf{1}}\right)$ & $\boldsymbol{n} \mathbf{( - )}$ & F-Ratio (-) & F-Critical (-) & $\boldsymbol{P}$-Value (-) & $\mathbf{R}^{\mathbf{2}} \mathbf{( - )}$ \\
\hline & 4.5 & $15.27 \pm 0.38$ & $0.033 \pm 0.001$ & & $0.093 \pm 0.057$ & $3.864 \pm 0.008$ & $0.767 \pm 0.074$ & $0.995 \pm 0.001$ \\
& 5.6 & $15.33 \pm 2.98$ & $0.034 \pm 0.004$ & & $0.077 \pm 0.041$ & $3.865 \pm 0.011$ & $0.786 \pm 0.057$ & $0.995 \pm 0.001$ \\
300 & 6.7 & $15.42 \pm 1.40$ & $0.033 \pm 0.002$ & 2 & $0.074 \pm 0.053$ & $3.866 \pm 0.011$ & $0.794 \pm 0.077$ & $0.996 \pm 0.001$ \\
& 8 & $17.52 \pm 3.73$ & $0.035 \pm 0.003$ & & $0.060 \pm 0.036$ & $3.866 \pm 0.005$ & $0.811 \pm 0.060$ & $0.996 \pm 0.001$ \\
& 10 & $16.41 \pm 0.33$ & $0.036 \pm 0.002$ & & $0.090 \pm 0.051$ & $3.866 \pm 0.007$ & $0.770 \pm 0.066$ & $0.995 \pm 0.001$ \\
\hline & 4.5 & $16.17 \pm 0.61$ & $0.031 \pm 0.001$ & & $0.031 \pm 0.003$ & $3.875 \pm 0.002$ & $0.862 \pm 0.006$ & $0.998 \pm 0.001$ \\
400 & 5.6 & $18.65 \pm 5.17$ & $0.034 \pm 0.004$ & & $0.050 \pm 0.021$ & $3.871 \pm 0.004$ & $0.826 \pm 0.036$ & $0.997 \pm 0.001$ \\
& 6.7 & $18.14 \pm 8.73$ & $0.036 \pm 0.004$ & 2 & $0.023 \pm 0.007$ & $3.872 \pm 0.001$ & $0.882 \pm 0.021$ & $0.9975 \pm 0.001$ \\
& 8 & $17.18 \pm 6.05$ & $0.032 \pm 0.005$ & & $0.038 \pm 0.002$ & $3.868 \pm 0.001$ & $0.845 \pm 0.005$ & $0.997 \pm 0.001$ \\
& 10 & $12.05 \pm 1.67$ & $0.031 \pm 0.001$ & & $0.045 \pm 0.014$ & $3.869 \pm 0.005$ & $0.833 \pm 0.026$ & $0.996 \pm 0.001$ \\
\hline
\end{tabular}

$A$ is the force coefficient of mechanical behaviour $(\mathrm{kN}), B$ is the deformation coefficient of mechanical behaviour $\left(\mathrm{mm}^{-1}\right), n$ is the fitting curve function exponent $(-)$, F-ratio is the value of the F test (-), F-critical is the critical value that compares a pair of models $(-), p$ value is the significance level used for testing a statistical hypothesis $(-), R^{2}$ is the coefficient of determination (-). $p$-value $>0.05$ or F-critical $>$ F-ratio means statistically significant [35]. 
The experimental and theoretical descriptions of the force and deformation curves of the densified briquettes of jatropha seedcake at a maximum force of $400 \mathrm{kN}$ and a speed of $5 \mathrm{~mm} \mathrm{~min}^{-1}$ are shown in Figure 6. A similar description was observed for the compression forces of 100, 200 and $300 \mathrm{kN}$ at the same speed for all experiments.

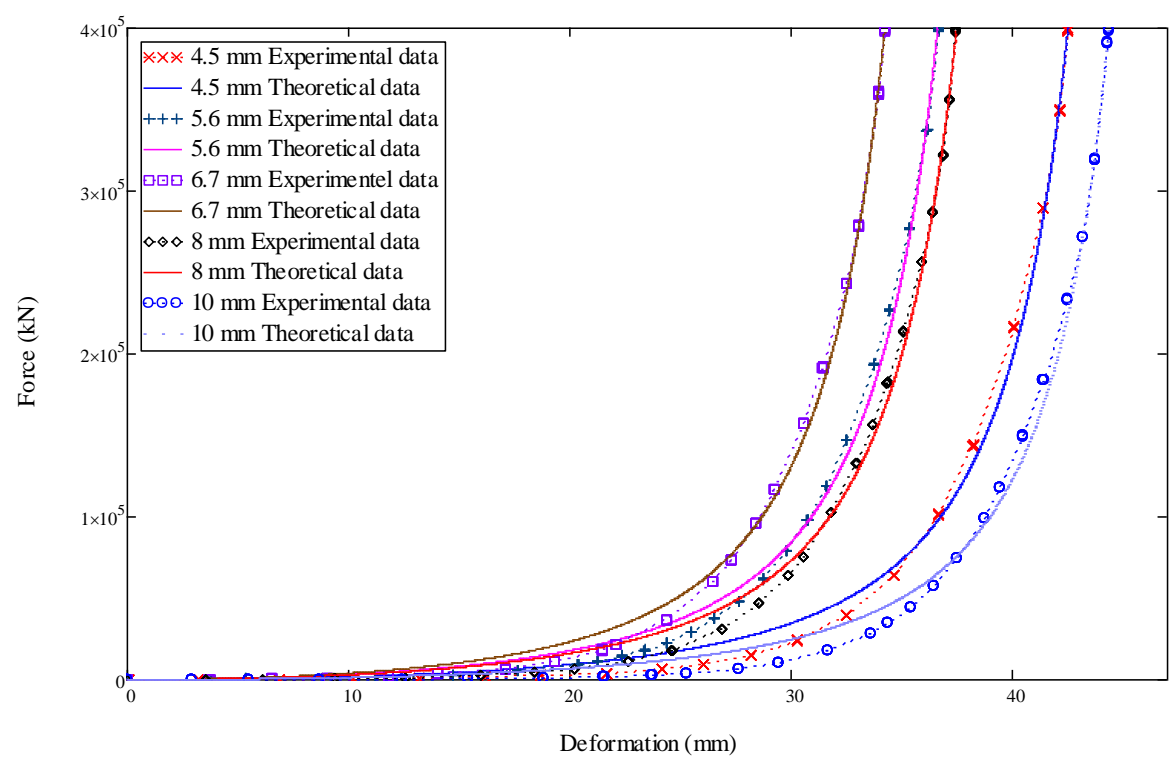

Figure 6. Description of force and deformation curves of experimental and theoretical data of densified jatropha seedcake briquettes of different dimensions at a maximum force of $400 \mathrm{kN}$ and a speed of $5 \mathrm{~mm} \mathrm{~min}^{-1}$.

\section{Discussion}

For the varying compression forces and sample dimensions, the deformation values ranged from $29.08 \pm 1.83$ to $44.64 \pm 0.42 \mathrm{~mm}$, thickness ranged from $30.49 \pm 0.01$ to $35.75 \pm 0.36 \mathrm{~mm}$, numerical energy ranged from $398.8 \pm 8.40$ to $1683.42 \pm 4.47 \mathrm{~J}$ and theoretical energy ranged from $420.74 \pm 0.45$ to $1894.03 \pm 68.11 \mathrm{~J}$.

The volume of samples of bulk jatropha seedcake of different dimensions or size distributions as described in Equation (1) was calculated to be $16.9646 \times 10^{-5} \mathrm{~m}^{3}$. The mass of samples at an initial height of $60 \mathrm{~mm}$ was $0.103 \mathrm{~kg}$, which remained constant in all the experiments. Here, the density of the samples was calculated to be $607.15 \mathrm{~kg} \mathrm{~m}^{-3}$. The volume of densified briquettes varied with the dimensions of the sample, as described by Equation (2). The increase of compression forces decreased the density of densified briquettes while the hardness increased. There was no clear correlation between density, hardness and samples dimensions. The energy per unit volume of densified briquettes and compression forces also showed no correlation in comparison with the dimensions of the sample that indicated a positive linear correlation.

The results of the multiple regression statistical analysis were statistically significant ( $p$-value $<0.05$ or F-ratio $>$ F-critical) [36]. This means that the independent variables (compression forces and samples dimensions) had a significant effect on the dependent variables (deformation, thickness, numerical energy and theoretical energy). The general linear models of the dependent variables are described in Equations (11)-(14). The coefficients of determination $\left(R^{2}\right)$ were $0.34,0.87,0.99$ and 0.96 respectively.

$$
\begin{aligned}
& \delta_{X}=32.48+0.03 \cdot F_{C}-0.22 \cdot D_{m} \\
& T_{X}=36.49-0.02 \cdot F_{C}+0.06 \cdot D_{m}
\end{aligned}
$$




$$
\begin{aligned}
& E_{N}=127.68+3.95 \cdot F_{C}-20.25 \cdot D_{m} \\
& E_{T}=167.52+4.29 \cdot F_{C}-26.88 \cdot D_{m}
\end{aligned}
$$

Based on the statistical analysis results, it is important to note that the model coefficients of the compression forces were significant $(p$-value $<0.05)$ for all the dependent variables. Similarly, the coefficients of the dimensions of the sample were significant but only for the numerical and theoretical energies. The deformation and thickness coefficients were not significant ( $p$-value $>0.05)$ [36] in relation to the dimensions of the sample. This means that there was no significant correlation between samples dimensions and dependent variables namely deformation $\delta_{X}$ and thickness $T_{x}$. Therefore, Equations (11) and (12) were modified as given in Equations (15) and (16) using the simple linear regression where the compression force $F_{C}$ was considered as the continuous regressor.

$$
\begin{aligned}
& \delta_{X}=31.83+0.03 \cdot F_{C} \\
& T_{X}=36.67-0.02 \cdot F_{C}
\end{aligned}
$$

The ANOVA statistical results of the determined coefficients of the tangent curve model (Equation (10)) using the Mathcad 14 software for a level of significance of 5\% were significant, that is, the values of F-critical were greater than the F-ratio values or the $p$-values were greater than the probability level of 0.05 [35]. This indicates that the tangent curve model is suitable for fitting the experimental dependency between force and deformation curves of bulk agricultural materials and/or products under compression loading [32-34]. The determined amounts of the force coefficient of mechanical behaviour $A$ for all compression forces $F_{C}$ and samples dimensions $D_{m}$ ranged between $5.07 \pm 1.032$ and $18.14 \pm 8.73 \mathrm{kN}$, while that of the deformation coefficient of mechanical behaviour $B$ ranged between $0.031 \pm 0.001$ and $0.045 \pm 0.002 \mathrm{~mm}^{-1}$. The fitting function exponent $n$ of the tangent model was found to be $2(-)$.

The numerical energy, Equation (8) $[27,28,32]$, is the area under the force and deformation curve $[31,37]$. It was theoretically determined by integrating Equation (10) for $n=2(-)$, which produced Equation (17) as follows:

$$
F(X)=A \cdot(\tan (B \cdot X))^{n=2} \rightarrow \frac{A \cdot(\tan (B \cdot X)-B \cdot X)}{B}
$$

The application of Equation (17) requires that the theoretical description of the experimental dependency between force and deformation curves, that is, the force coefficient of mechanical behaviour $A(\mathrm{kN})$, the deformation coefficient of mechanical behaviour $B\left(\mathrm{~mm}^{-1}\right)$ and the fitting function exponent $n(-)$ must be determined using Equation (10). To emphasize more the numerical energy of the densified briquettes, it was seen that the increase in densified briquettes dimensions or size distributions decreased the energy. This suggests that the sample dimension of $10 \mathrm{~mm}$ could be economically viable for briquette energy sources. However, for assessing the quality of biomass briquettes with respect to energy demand, it is necessary to examine the physical properties such as the durability, compressive strength, calorific value, moisture content and binders for briquette formation. The study results are part of the comprehensive knowledge required for designing optimal technology for producing solid biofuels biomass briquettes as a renewable energy resource.

\section{Conclusions}

The increase in compaction forces increased the hardness of the jatropha seedcake briquettes. Compaction forces had a significant effect on briquettes deformation and thickness, while the dimensions of the sample did not. The increase in samples dimensions decreased the briquettes' compaction energy. Sample dimensions of $4.5 \mathrm{~mm}$ recorded the highest energy, compared to those of the $10 \mathrm{~mm}$, which had the lowest. The determined coefficients of the tangent curve mathematical 
model theoretically described the experimental data, that is, the dependency between the force and deformation curves of the jatropha seedcake briquettes at different dimensions and forces.

Supplementary Materials: The following are available online at http://www.mdpi.com/1996-1073/11/8/1980/s1.

Author Contributions: Conceptualization, T.I., A.K. and D.H.; Data curation, D.H.; Formal analysis, A.K. and C.D.; Funding acquisition, T.I.; Investigation, A.K. and C.D.; Methodology, T.I.; Project administration, T.I. and A.K.; Resources, T.I.; Writing-original draft, A.K.; Writing-review \& editing, T.I. and D.H.

Acknowledgments: The research was supported by the Internal Grant Agency of the Faculty of Tropical AgriSciences, Czech University of Life Sciences Prague [grant number 20175011 and 20185011].

Conflicts of Interest: The authors declare no conflict of interest.

\section{References}

1. Navarro-Pineda, F.S.; Baz-Rodriguez, S.A.; Handler, R.; Sacramento-Rivero, J.C. Advances on the processing of Jatropha curcas towards a whole-crop biorefinery. Renew. Sustain. Energy Rev. 2016, 54, 247-269. [CrossRef]

2. Contran, N.; Chessa, L.; Lubino, M.; Bellavite, D.; Lobina, R.; Sahanoon, O.; Fuseini, S.; Imoro, T.S.; Roggero, P.P.; Enne, G. Potentialities and limits of Jatropha curcas L. as alternative energy source to traditional energy sources in Northern Ghana. Energy Sustain. Dev. 2016, 31, 163-169. [CrossRef]

3. Heller, J. Physic nut, Jatropha curcas L-Promoting the Conservation and Use of Underutilized and Neglected Crops; International Plant Genetic Resources Institute: Rome, Italy, 1996; pp. 1-66, ISBN 92-9043-278-0.

4. Ye, M.; Li, C.Y.; Francis, G.; Makkar, H.P.S. Current situation and prospects of Jatropha curcas as a multipurpose tree in China. Agrofor. Syst. 2009, 76, 487-497. [CrossRef]

5. Kongkasawan, J.; Nam, H.; Capareda, S.C. Jatropha waste meal as an alternative energy source via pressurized pyrolysis: A study on temperature effects. Energy 2016, 113, 631-642. [CrossRef]

6. Afonso, T.L.; Marques, A.C.; Fuinhas, J.A. Strategies to make renewable energy sources compatible with economic growth. Energy Strateg. Rev. 2017, 18, 121-126. [CrossRef]

7. Dincer, I. Renewable energy and sustainable development: A crucial review. Renew. Sustain. Energy Rev. 2000, 4, 157-175. [CrossRef]

8. Lind, A.; Rosenberg, E.; Seljom, P.; Espegren, A.; Fidje, A.; Lindberg, K. Analysis of the EU renewable energy directive by a techno-economic optimisation model. Energy Policy 2013, 60, 364-377. [CrossRef]

9. Chen, L.; Xing, L.; Han, L. Renewable energy from agro-residues in china: Solid biofuels and biomass briquetting technology. Renew. Sustain. Energy Rev. 2009, 13, 2689-2695. [CrossRef]

10. Agrawalla, A.; Kumar, S.; Singh, R.K. Pyrolysis of groundnut de-oiled cake and characterization of the liquid product. Bioresour. Technol. 2011, 102, 10711-10716. [CrossRef] [PubMed]

11. Chen, Y.; Duan, J.; Luo, Y.-h. Investigation of agricultural residues pyrolysis behaviour under inert and oxidative conditions. J. Anal. Appl. Pyrolysis 2008, 83, 165-174. [CrossRef]

12. Demirbas, A. Effects of temperature and particle size on bio-char yield from pyrolysis of agricultural residues. J. Anal. Appl. Pyrolysis 2004, 72, 243-248. [CrossRef]

13. Yank, A.; Ngadi, M.; Kok, R. Physical properties of rice husk and bran briquettes under low pressure densification for rural applications. Biomass Bioenergy 2016, 84, 22-30. [CrossRef]

14. Shuma, R.; Madyira, D.M. Production of loose biomass briquettes from agricultural and forestry residues. Procedia Manuf. 2017, 7, 98-105. [CrossRef]

15. Moreno, A.I.; Font, R.; Conesa, J.A. Physical and chemical evaluation of furniture waste briquettes. Waste Manag. 2016, 49, 245-252. [CrossRef] [PubMed]

16. Ishii, K.; Furuichi, T. Influence of moisture content, particle size and forming temperature on productivity and quality of rice straw pellets. Waste Manag. 2014, 34, 2621-2626. [CrossRef] [PubMed]

17. Kaliyan, N.; Morey, R.V. Strategies to improve durability of switchgrass briquettes. Trans. ASABE 2009, 52, 1943-1953. [CrossRef]

18. Križan, P.; ŠooŠ, L.; Vukelic, D. A study of impact technological parameters on the briquetting process. Facta Univ. Ser. Work. Living Environ. Prot. 2009, 6, 39-47.

19. Lee, S.M.; Ahn, B.J.; Choi, D.H.; Han, G.S.; Jeong, H.S.; Ahn, S.H.; Yang, I. Effects of densification variables on the durability of wood pellets fabricated with Larix kaempferi C. and Liriodendron tulipifera L. sawdust. Biomass Bioenergy 2013, 48, 1-9. [CrossRef] 
20. Stelte, W.; Holm, J.K.; Sanadi, A.R.; Barsberg, S.; Ahrenfeldt, J.; Henriksen, U.B. A study of bonding and failure mechanisms in fuel pellets from different biomass resources. Biomass Bioenergy 2011, 35, 910-918. [CrossRef]

21. ČSN EN ISO 17827-1. Solid Biofuels—Determination of Particle Size Distribution for Uncompressed Fuels—Part 1: Oscillating Screen Method Using Sieves with Apertures of $3.15 \mathrm{~mm}$ and above; Czech Office for Standards, Metrology and Testing: Prague, Czech Republic, 2016; pp. 1-20.

22. Chaloupková, V.; Ivanova, T.; Ekrt, O.; Kabutey, A.; Herák, D. Determination of particle size and distribution through image-based macroscopic analysis of the structure of biomass briquettes. Energies 2018, 11, 331. [CrossRef]

23. BS EN ISO 18134-3. Solid Biofuels_Determination in Moisture Content_Oven Dry Method_Part 3: Moisture in General Analysis Sample; BSI Standards Publication: Bonn, Germany, 2015; pp. 1-14.

24. Malat'ák, J.; Branda, J. Use of waste material mixtures for energy purposes in small combustion devices. Res. Agric. Eng. 2014, 60, 50-59. [CrossRef]

25. Muntean, A.; Ivanova, T.; Hutla, P.; Havrland, B. Influence of raw material properties on the quality of solid biofuel and energy consumption in briquetting process. Agron. Res. 2017, 15, 1708-1715. [CrossRef]

26. Herak, D.; Kabutey, A.; Divisova, M.; Simanjuntak, S. Mathematical model of mechanical behaviour of Jatropha curcas L. seeds under compression loading. Biosyst. Eng. 2013, 114, 279-288. [CrossRef]

27. Demirel, C.; Kabutey, A.; Herak, D.; Gurdil, G.A.K. Numerical estimation of deformation energy of selected bulk oilseeds in compression loading. IOP Conf. Ser. Mater. Sci. Eng. 2017, 237, 1-5. [CrossRef]

28. Divišová, M.; Herák, D.; Kabutey, A.; Sigalingging, R.; Svatoňová, T. Deformation curve characteristics of rapeseeds and sunflower seeds under compression loading. Sci. Agric. Bohem. 2014, 45, 180-186. [CrossRef]

29. Herák, D.; Kabutey, A.; Sedláček, A.; Gurdil, G. Mechanical behaviour of several layers of selected plant seeds under compression loading. Res. Agric. Eng. 2012, 58, 24-29. [CrossRef]

30. Chakespari, A.G.; Rajebipour, A.; Mobli, H. Anisotropic relaxation and creep properties of apple (cv. Shafi Abadi and Golab Kohanz). Adv. J. Food Sci. Technol. 2010, 2, 200-205.

31. Gupta, R.K.; Das, S.K. Fracture resistance of sunflower seed and kernel to compressive loading. J. Food Eng. 2000, 46, 1-8. [CrossRef]

32. Herák, D.; Kabutey, A.; Sedláček, A.; Gurdil, G. Tangent curve utilization for description of mechanical behaviour of preseed mixture. Res. Agric. Eng. 2011, 57, 13-18. [CrossRef]

33. Sigalingging, R.; Herák, D.; Kabutey, A.; Čestmír, M.; Divišová, M. Tangent curve function description of mechanical behaviour of bulk oilseeds: A review. Sci. Agric. Bohem. 2014, 45, 259-264. [CrossRef]

34. Sigalingging, R.; Herák, D.; Kabutey, A.; Dajbych, O.; Hrabě, P.; Mizera, C. Application of a tangent curve mathematical model for analysis of the mechanical behaviour of sunflower bulk seeds. Int. Agrophysics 2015, 29, 517-524. [CrossRef]

35. Parametric Technology Corporation. Mathsoft; Parametric Technology Corporation: Needham, MA, USA, 2014.

36. StatSoft, Inc. Statsoft; StatSoft, Inc.: Tulsa, OK, USA, 2013.

37. Lysiak, G. Fracture toughness of pea: Weibull analysis. J. Food Eng. 2007, 83, 436-443. [CrossRef]

(C) 2018 by the authors. Licensee MDPI, Basel, Switzerland. This article is an open access article distributed under the terms and conditions of the Creative Commons Attribution (CC BY) license (http:/ / creativecommons.org/licenses/by/4.0/). 